\title{
Molecular detection and serotypic analysis of enterovirus RNA in archival specimens from patients with acute myocarditis
}

Department of
Virology, United
Medical and Dental
Schools of Guy's and
St Thomas' (St
Thomas' campus)
London
F Nicholson
J F Ajetunmobi
M Li
E A Shackleton
W G Starkey
S J Illavia
P Muir
J E Banatvala
Correspondence to:
Dr P Muir, Department of
Virology, United Medical
and Dental Schools of Guy's
and St Thomas' (St Thomas'
campus), London SE1 7EH.
Accepted for publication
12 June 1995

F Nicholson, J F Ajetunmobi, M Li, E A Shackleton, W G Starkey, S J Illavia, P Muir, J E Banatvala

\begin{abstract}
Objective-To determine whether enterovirus RNA can be demonstrated in archival necropsy material in acute myocarditis.

Design-Analysis of paraffin embedded myocardial tissue from cases of acute myocarditis.

Setting-University virology department. Methods-Extraction of RNA from tissue followed by polymerase chain reaction (PCR) and DNA sequence analysis.

Patients-Six patients with histologically proven myocarditis and eight controls.

Results-Enterovirus RNA was identified in 5 of 6 patients with myocarditis and in none of the controls. The nucleotide sequences of the PCR products showed greatest similarity to group B coxsackieviruses, particularly coxsackievirus B3. Conclusion-This study indicates that archival tissue samples, even histologically stained tissue sections, can be used to study the role of enteroviruses in myocardial disease using molecular detection techniques. If a predominant role for coxsackievirus B3 in myocarditis is confirmed by further study, this may have implications for the development of a specific vaccine.
\end{abstract}

(Br Heart f 1995;74:522-527)

Keywords: enterovirus RNA, acute myocarditis, polymerase chain reaction, nucleotide sequence analysis

Enteroviruses are the commonest viral cause of acute myocarditis. ${ }^{1}$ Establishing a diagnosis is not straightforward, however, as a history of a recent viral illness cannot always be obtained and histological features of endomyocardial biopsy specimens do not allow differentiation between viral and other causes of myocarditis. Furthermore, histological evidence of myocarditis may frequently be missed because of the focal nature of lesions. Traditional diagnostic methods, including virus isolation in cell culture, detection of viral antigen in biopsy or necropsy tissue, and detection of rising antibody titres, are frequently unsuccessful as cardiac symptoms usually coincide with the onset of cytotoxic $\mathrm{T}$ cell responses directed against viral or cellular antigens that occur late in the disease process. Although enterovirus specific immunoglobulin $M$ (IgM) antibody may be detected in up to $50 \%$ of cases, ${ }^{2-4}$ results must be interpreted carefully as there may be a high background prevalence of IgM responses in the general population, particularly during epidemic seasons. ${ }^{5}$

Such techniques as slot blot and in situ hybridisation have been employed to detect viral RNA in acute myocarditis ${ }^{6-8}$ but are not suitable for use in diagnostic laboratories as they are too labour intensive. Reverse transcription (RT) and polymerase chain reaction (PCR) amplification of viral RNA are potentially more rapid and sensitive but have not been adequately evaluated for the diagnosis of viral myocarditis.

We have previously described a specific nested RT and PCR for the detection of enteroviral RNA in clinical samples, which is at least 10 times more sensitive than cell culture detection. ${ }^{12}$ This paper describes how these studies have been extended to detect enteroviral RNA retrospectively in formalin fixed archival myocardial tissue including haematoxylin and eosin ( $\mathrm{H}$ and $\mathrm{E}$ ) stained sections. In addition, we have used nested or semi-nested RT and PCR assays to amplify three different regions of the viral genome (two in the $5^{\prime}$ non-translated region ( $5^{\prime}$ NTR) and one in the capsid (VP2) coding region) to exclude the possibility of false positivity due to PCR product contamination. We have also sequenced PCR products derived from the $5^{\prime}$ NTR, thereby enabling us to determine the enterovirus serotype present in heart tissue. We also detected enteroviral RNA using an in situ hybridisation protocol under evaluation in this laboratory which utilises non-isotopic probes and is therefore potentially more suitable for diagnostic use than previously described protocols employing radioactive probes requiring prolonged autoradiographic exposure. Results of these molecular investigations have been correlated with clinical findings and results of enterovirus specific IgM testing.

\section{Materials and methods}

CLINICAL SAMPLES

Postmortem heart samples were obtained from five patients with fatal myocarditis conforming with the Dallas criteria, ${ }^{9}$ and an additional patient with giant cell myocarditis (age range from 3.5 weeks to 32 years). Table 1 gives the presenting histories of patients together with samples obtained. A comparison group con- 
Table 1 Patient characteristics

\begin{tabular}{|c|c|c|c|c|}
\hline Patient & Sex & $\begin{array}{l}\text { Age } \\
\text { (years) }\end{array}$ & Samples & Clinical presentation \\
\hline 1 & $\mathbf{M}$ & 11 & $\mathrm{Bx}, \mathrm{FFB}$ & $\begin{array}{l}4 \text { day history of headaches and } \\
\text { vomiting, neck pain, fever }\end{array}$ \\
\hline $\begin{array}{l}2 \\
3 \\
4 \\
5\end{array}$ & $\begin{array}{l}\mathrm{F} \\
\mathrm{M} \\
\mathrm{M} \\
\mathrm{M}\end{array}$ & $\begin{array}{l}32 \\
3 \cdot 5 \mathrm{wk} \\
21 \\
25\end{array}$ & $\begin{array}{l}\text { FFB } \\
\mathrm{H} \text { and } \mathrm{E}, \mathrm{FFB} \\
\text { FFB } \\
\mathrm{H} \text { and } \mathrm{E}\end{array}$ & $\begin{array}{l}\text { Died postpartum after febrile illness } \\
\text { Developed cardiac failure aged } 11 \text { days } \\
\text { Epigastric pain, short of breath } \\
\text { Dizzy, palpitations, falling cardiac } \\
\text { output }\end{array}$ \\
\hline 6 & $\mathrm{~F}$ & 25 & $\mathrm{H}$ and $\mathrm{E}$ & $\begin{array}{l}\text { Sore throat, lymphadenopathy rash, } \\
\text { arthralgia, myalgia }\end{array}$ \\
\hline
\end{tabular}

Bx, biopsy; FFB, formalin fixed block; $\mathrm{H}$ and $\mathrm{E}$, haematoxylin and eosin stained tissue.

\section{Table 2 Control patients}

\begin{tabular}{lllll}
\hline Control & Sex & Age (years) & Samples & Diagnosis \\
\hline 1 & M & 13 & FFB & Cerebrovascular accident \\
2 & F & 32 & FFB & Subarachnoid haemorrhage \\
3 & M & 12 wk & H and E & Bacterial meningitis \\
4 & M & 28 & FFB & Brain tumour \\
5 & M & 26 & H and E & Septicaemia \\
6 & M & 35 & FFB & Pneumonia \\
7 & F & 66 & FFB & Cerebral infarction \\
8 & F & 42 & FFB & Pancreatic carcinoma \\
\hline
\end{tabular}

Abbreviations as in table 1 .

sisted of heart tissue from eight patients (age range 12 weeks to 66 years) who died of noncardiological causes (table 2). Antemortem serum samples were available from five of six patients with acute myocarditis and were tested for the presence of enterovirus specific IgM. ${ }^{10}$

\section{RNA EXTRACTION}

$H$ and $E$ preparations

Slides were soaked in xylene for $48 \mathrm{~h}$, immersed in ethanol for five min, and then dried in air. The coverslip was removed with a scalpel blade and the section scraped off and suspended in $100 \mu \mathrm{l}$ of digestion buffer containing $100 \mathrm{mmol} / \mathrm{l}$ sodium chloride, $10 \mathrm{mmol} / 1$ TRIS hydrochloride $(\mathrm{HCl})(\mathrm{pH}$ $8 \cdot 0$ ), $25 \mathrm{mmol} / 1$ EDTA, $0.5 \%$ sodium dodecyl sulphate, and $0.1 \mathrm{mg} / \mathrm{ml}$ nuclease free proteinase K (Sigma; Poole, Dorset). Samples were incubated with gentle agitation at $37^{\circ} \mathrm{C}$

Table 3 Oligonucleotide primers used for reverse transcription and polymerase chain reaction amplification of enterovirus $R N A$

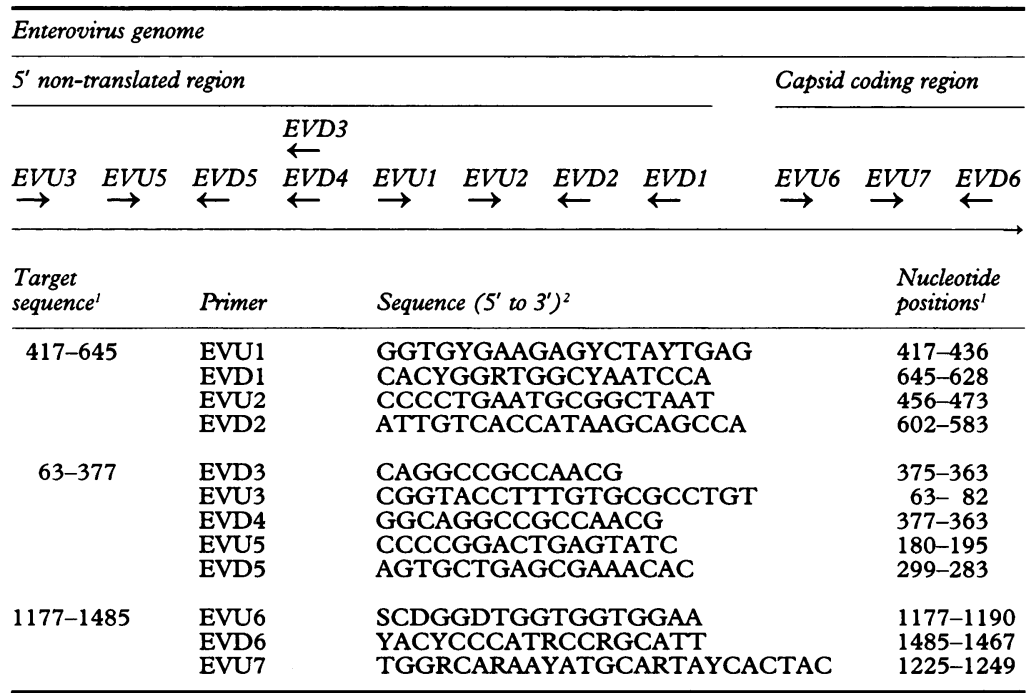

${ }^{1}$ Nucleotide positions based on those of Klump et al. ${ }^{14}$

${ }^{2}$ Redundant base codes: $\mathrm{Y}=\mathrm{C}$ or $\mathrm{T} ; \mathrm{R}=\mathrm{A}$ or $\mathrm{G} ; \mathrm{S}=\mathrm{C}$ or $\mathrm{G} ; \mathrm{D}=\mathrm{A}, \mathrm{G}$ or $\mathrm{T}$. for three days after which a further $50 \mu \mathrm{g}$ proteinase $\mathrm{K}$ was added to each tube and left to digest for a further 3-4 days. RNA was extracted from the supernatant using RNAzol B (Biotex, Houston, Texas) as previously described, ${ }^{11}$ stored as dry pellets at $-70^{\circ} \mathrm{C}$, and reconstituted in sterile water immediately before use.

\section{Formalin fixed paraffin embedded sections}

Thick sections $(10 \mu \mathrm{m})$ were dewaxed by washing twice in octane at room temperature for 30 min with mixing and twice in ethanol. The sections were dried at $37^{\circ} \mathrm{C}$. About $10 \mu \mathrm{g}$ tissue were suspended in $100 \mu \mathrm{l}$ of digestion buffer containing $50 \mathrm{mmol} / 1$ TRIS ( $\mathrm{pH} \mathrm{8.0)}$ ), $1 \mathrm{mmol} / \mathrm{l}$ EDTA, $0.5 \%$ Tween 20, and $10 \mathrm{mmol} / 1$ vanadyl ribonucleoside complexes (Gibco BRL, Paisley) with nuclease free proteinase K (Sigma) added immediately before use to a final concentration of $200 \mu \mathrm{g} / \mathrm{ml}$. Samples were incubated at $55^{\circ} \mathrm{C}$ for $180 \mathrm{~min}$, and then at $99^{\circ} \mathrm{C}$ for $5 \mathrm{~min}$ to inactivate the enzyme. RNA was extracted from the supernatant using RNAzol B.

Oligonucleotides-Table 3 shows the oligonucleotide primers used for RT and PCR. Optimal primer sequences were predicted using OLIGO 4.0 (National Biosciences Plymouth, Minnestota, USA). Primers EVU1, EVD1, EVU2, and EVD2 were designed using all published enterovirus sequences currently available and recognise highly conserved sequences within the $5^{\prime} \mathrm{NTR}$ of the enterovirus genome. We have shown that nested PCR using these primers is able to detect a wide range of enterovirus serotypes, including all polioviruses and group B coxsackieviruses and representative group A coxsackieviruses and echoviruses, as well as enterovirus $70 . .^{112}$ Other primers described in table 3 were designed using published group B coxsackievirus (CVB) sequences, namely CVB1, ${ }^{13}$ CVB3, ${ }^{14}$ CVB4, ${ }^{15}$ and CVB5. ${ }^{16}$ PCR assays using these primers have been shown to detect all six CVB serotypes (not shown). Their ability to detect other enterovirus serotypes is currently under investigation.

$R T$ and PCR amplification-Viral RNA was amplified by RT and nested or semi-nested PCR using three sets of primers to amplify distinct regions of the viral genome. Nested RT and PCR using primers EVD1/EVU1 and EVD2/EVU2 were carried out as previously described. ${ }^{12}$ Amplification of the other two regions of the genome was carried out similarly using primers for RT and PCR and optimal magnesium chloride concentrations, primer annealing temperature, and cycle number for each primer pair as shown in table 4 .

$P C R$ contamination prevention strategySections of paraffin embedded tissue were prepared using a microtome with disposable blades. A new blade was used for each block. Negative extraction and reagent controls were processed alongside each batch of test specimens to ensure that PCR contamination did not occur. Other safeguards established to minimise the risk of contamination have already been described. ${ }^{11} 12$ 
Table 4 Oligonucleotide primers used for reverse transcription and polymerase chain reaction amplification of enterovirus $R N A$

\begin{tabular}{|c|c|c|c|c|c|c|c|c|c|}
\hline \multirow[b]{2}{*}{$\begin{array}{l}\text { Target } \\
\text { sequence }\end{array}$} & \multirow[b]{2}{*}{$\begin{array}{l}\text { Reverse } \\
\text { transcription } \\
\text { primer }\end{array}$} & \multirow[b]{2}{*}{$\begin{array}{l}\text { Primers } \\
\text { (size of } \\
\text { product) }\end{array}$} & \multicolumn{3}{|l|}{ First PCR } & \multicolumn{4}{|c|}{ Second PCR } \\
\hline & & & $\begin{array}{l}\mathrm{MgCl}_{2} \\
\text { concentration } \\
\text { (mmol/l) }\end{array}$ & $\begin{array}{l}\text { Annealing } \\
\text { temperature } \\
\left({ }^{\circ} \mathrm{C}\right)\end{array}$ & $\begin{array}{l}\text { Cycle } \\
\text { number }\end{array}$ & $\begin{array}{l}\text { Primers } \\
\text { (size of } \\
\text { product) }\end{array}$ & $\begin{array}{l}\mathrm{MgCl}_{2} \\
\text { Concentration } \\
\text { (mmolll) }\end{array}$ & $\begin{array}{l}\text { Annealing } \\
\text { temperature } \\
\left({ }^{\circ} \mathrm{C}\right)\end{array}$ & $\begin{array}{l}\text { Cycle } \\
\text { number }\end{array}$ \\
\hline $417-645$ & EVD1 & $\begin{array}{l}\text { EVU1 } \\
\text { EVD1 } \\
(229 \text { bp) }\end{array}$ & $2 \cdot 0$ & 50 & 30 & $\begin{array}{l}\text { EVD2 } \\
\text { EVD2 } \\
(147 \text { bp })\end{array}$ & $1 \cdot 8$ & 52 & 25 \\
\hline $63-377$ & EVD3 & $\begin{array}{l}\text { EVU3 } \\
\text { EVD4 } \\
\text { (315 bp) }\end{array}$ & $2 \cdot 0$ & 58 & 40 & $\begin{array}{l}\text { EVU5 } \\
\text { EVD5 } \\
(120 \text { bp })\end{array}$ & $2 \cdot 4$ & 49 & 15 \\
\hline $1177-1485$ & EVD6 & $\begin{array}{l}\text { EVU6 } \\
\text { EVD6 } \\
\text { (309 bp) }\end{array}$ & $2 \cdot 6$ & 55 & 40 & $\begin{array}{l}\text { EVU7 } \\
\text { EVD6 } \\
\text { (261 bp) }\end{array}$ & $1 \cdot 4$ & 50 & 15 \\
\hline
\end{tabular}

bp, base pairs; $\mathrm{MgCl}_{2}$, magnesium chloride.

\section{Probe preparation}

A CVB3 complementary DNA clone (pCB3) and control plasmid ( $\mathrm{p} 2723$ ) were used to generate enterovirus specific and control cDNA probes respectively. ${ }^{17}$ A $6.2 \mathrm{~kb} \mathrm{Kpn} \mathrm{I} \mathrm{fragment}$ and $1.0 \mathrm{~kb} B a m \mathrm{HI}$ fragment of clone pCB3 were isolated ${ }^{18}$ and further restricted with $M n l \mathrm{I}$ to generate fragments of optimal length for use as in situ probes (predominantly $70-200$ base pairs). DNA fragments were labelled overnight with digoxygenin employing a digoxygenin high prime labelling kit (Boehringer Mannheim Lewes, East Sussex) using 30 ng template DNA per 1.4 pmol digoxygenin-11-deoxyuridine triphosphate-that is, $4 \mu \mathrm{l}$ labelling mix). Digoxygenin labelled DNA was precipitated, redissolved in $50 \mu \mathrm{l} 0 \cdot 1 \mathrm{~mol} / \mathrm{l}$ Tris EDTA buffer, $\mathrm{pH} 8 \cdot 0$, and used at a dilution of 1:400 for in situ hybridisation. Control plasmid p2723 was restricted with $M n l$ I and labelled with digoxygenin in the same way.

\section{In situ hybridisation}

Sections $(5 \mu \mathrm{m})$ of paraffin embedded formalin fixed myocardial tissue were mounted on silane coated slides, dried at $37^{\circ} \mathrm{C}$ overnight, dewaxed by immersing in two changes of xylene, and rehydrated by two successive immersions in each of 99, 95, 70, and 50\% industrial methylated spirit, then in diethylpyrocarbonate treated sterile water. All subsequent pre- and post-hybridisation incubations and washing stages were carried out using the Omnislide thermal cycler and wash module (Hybaid, Teddington) except where stated. All incubations and washes were at room temperature except where stated. Nuclease- and protease-free reagents and solutions were used for prehybridisation, hybridisation, and posthybridisation washes. Sections were washed successively in $2 \times$ saline sodium citrate (SSC) (Sigma; $1 \times$ SSC consists of $15 \mathrm{mmol} / 1$ sodium citrate and $150 \mathrm{mmol} / \mathrm{l}$ sodium chloride) for $10 \mathrm{~min}$ at $60^{\circ} \mathrm{C}$, diethyl pyrocarbonate treated sterile water for $10 \mathrm{~s}$, and then $50 \mathrm{mmol} / \mathrm{l} \mathrm{TRIS} \mathrm{HCl}$ ( $\mathrm{pH} \mathrm{7} 6$ ) (Sigma) for 5 min. Tissue sections were rendered permeable by digestion with $12.5 \mu \mathrm{g} / \mathrm{ml}$ proteinase $\mathrm{K}$ in $50 \mathrm{mmol} / 1$ TRIS $\mathrm{HCl}(\mathrm{pH} 7 \cdot 6)$ for $1 \mathrm{~h}$ at $37^{\circ} \mathrm{C}$. Slides were then divided into two groups. One group was treated with $100 \mu \mathrm{g} / \mathrm{ml}$ ribonuclease (RNase) (Sigma) in $2 \times$ SSC containing $10 \mathrm{mmol} / \mathrm{l}$ magnesium chloride for $1 \mathrm{~h}$ at $37^{\circ} \mathrm{C}$ (RNase controls). The other group was treated in RNase free buffer. The two groups of slides were washed separately in diethyl pyrocarbonate phosphate buffered saline (Sigma) for $10 \mathrm{~s}$ and post fixed in $4 \%$ $(w / v)$ paraformaldehyde in diethyl pyrocarbonate treated $0.01 \mathrm{~mol} / 1$ phosphate buffered saline at $4^{\circ} \mathrm{C}$ for $20 \mathrm{~min}$. RNase treatment, washing, and paraformaldehyde fixation of slides were performed in baked glass chambers. Slides were then combined and washed in diethyl pyrocarbonate treated sterile water for $10 \mathrm{~s}$ and prehybridised using a minimal volume of hybridisation buffer $(3 \times$ SSC in $50 \mathrm{mmol} / \mathrm{l}$ TRIS $\mathrm{HCl}(\mathrm{pH} \mathrm{7.6})$ containing $10 \%$ dextran sulphate, $30 \%$ formamide, $150 \mu \mathrm{g} / \mathrm{ml}$ salmon sperm DNA, $0 \cdot 1 \%$ sodium pyrophosphate, $0 \cdot 2 \%$ polyvinylpyrrolidone, and $5 \mathrm{mmol} / \mathrm{l}$ EDTA) for $1 \mathrm{~h}$ at $37^{\circ} \mathrm{C}$. Hybridisation buffer was aspirated, replaced with fresh buffer containing digoxygenin labelled enterovirus specific or control heat denatured probe at a dilution of 1:400 and slides incubated at $95^{\circ} \mathrm{C}$ for $5 \mathrm{~min}$ then $37^{\circ} \mathrm{C}$ overnight. Post-hybridisation washes consisted of successive washes at $37^{\circ} \mathrm{C}$ in $4 \times$ SSC containing $50 \%$ formamide (twice) then $2 \times$ SSC containing $50 \%$ formamide (twice). Sections were blocked with $5 \%$ sheep serum in modified TRIS buffered saline $(50 \mathrm{mmol} / \mathrm{l}$ TRIS $\mathrm{HCl}(\mathrm{pH} 7 \cdot 6), 150 \mathrm{mmol} / \mathrm{l}$ sodium chloride, 2 $\mathrm{mmol} / \mathrm{l}$ magnesium chloride, $0 \cdot 1 \%$ filtered bovine serum albumin) for $1 \mathrm{~h}$, drained, and incubated with alkaline phosphatase labelled anti-digoxygenin $\mathrm{Fab}$ antibody fragments (Boehringer Mannheim) diluted 1:600 in modified TRIS buffered saline for $1 \mathrm{~h}$, then washed twice with modified TRIS buffered saline for $5 \mathrm{~min}$ and once with diethyl pyrocarbonate treated sterile water for $1 \mathrm{~min}$. To detect bound probe, sections were covered with $0 \cdot 1 \mathrm{~mol} / 1 \mathrm{TRIS} \mathrm{HCl}(\mathrm{pH} 9 \cdot 5)$, containing $1 \mathrm{~mol} / 1$ sodium chloride, $1 \mathrm{mmol} / 1$ magnesium chloride, $1 \mathrm{mmol} / 1$ levamisole, $0.33 \mathrm{mg} / \mathrm{mlni}-$ troblue tetrazolium, (Boehringer Mannheim), and $0.17 \mathrm{mg} / \mathrm{ml}$ 5-bromo-4-bromo-3-indoylphosphate (Boehringer Mannheim), and incubated overnight in the dark. Slides were washed for $5 \mathrm{~min}$ in water, mounted in ultraviolet free aqueous mountant (RA Lamb London), and viewed by light microscopy. In some cases sections were counterstained with $1 \%$ malachite green before mounting. Specific hybridisation signals were identified as discrete areas of purplish brown colour which were 
Table 5 Results of enterovirus PCR, nucleotide sequence analysis of PCR products, and enterovirus specific IgM testing in patients with acute myocarditis and in controls

\begin{tabular}{|c|c|c|c|c|c|c|}
\hline \multirow[b]{2}{*}{ No } & \multicolumn{3}{|c|}{ Polymerase chain reaction } & \multirow{2}{*}{$\begin{array}{l}\text { Closest } \\
\text { sequence } \\
\text { identity }\end{array}$} & \multirow[b]{2}{*}{ Homology $y^{2}$} & \multirow[b]{2}{*}{$\operatorname{Ig} M$} \\
\hline & $\#$ \#17-645 & $63-377$ & $1177-1485$ & & & \\
\hline \multicolumn{7}{|c|}{ Patient } \\
\hline 1 & + & + & - & B3 & 100 & $\mathrm{X}$ \\
\hline 2 & + & + & + & B3 & 100 & - \\
\hline 3 & + & + & $\mathbf{X}$ & B5 & 97 & + \\
\hline 4 & + & + & + & B3 & 100 & + \\
\hline 5 & + & + & - & B3 & 100 & + \\
\hline 6 & - & - & $\mathrm{X}$ & - & - & + \\
\hline \multicolumn{7}{|c|}{ Controls } \\
\hline 1 & - & - & - & - & - & $\mathrm{X}$ \\
\hline 2 & - & - & - & - & - & $\mathbf{X}$ \\
\hline 3 & - & - & - & - & - & $\mathrm{X}$ \\
\hline 4 & - & - & - & - & - & $\mathrm{X}$ \\
\hline 5 & - & - & - & - & - & $\mathrm{X}$ \\
\hline 6 & - & - & - & - & - & $\mathrm{X}$ \\
\hline 7 & - & - & - & - & - & $\mathrm{X}$ \\
\hline 8 & - & - & - & - & - & $\mathbf{X}$ \\
\hline
\end{tabular}

Based on sequence analysis of EVU1/EVD1 nested polymerase chain reaction products. $\mathrm{X}$, not tested.

Figure 1 Enterovirus $R N A$ in formalin fixed myocardium detected by amplification of nucleotides 63-377 (tracks 2-7), 417-645 (tracks 8-13), and 1177-1485 (tracks 14-19) of the enterovirus genome. Track 1, DNA molecular weight markers (kb ladder; GIBCO BRL). Tracks 2, 8, and chain reaction (PCR) products derived from coxsackievirus B3 (CVB3) RNA (positive contol), tracks 3, 9, and 15 , second $P C R$ products derived from patient 2 , tracks 4-7, 10-13, and 16-19, PCR negative controls. 14 , second polymerase

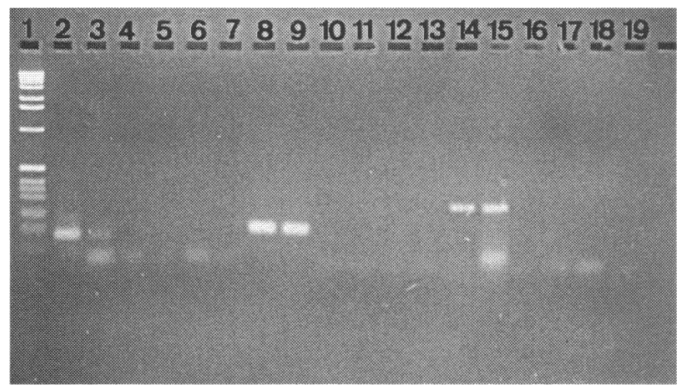

present in sections hybridised with enterovirus specific probe but were not present in replicate sections hybridised with control plasmid probe, and were either absent or greatly reduced in intensity in replicate $R$ Nase control sections.

\section{PCR product sequence analysis}

Biotinylated nested PCR products were generated for sequence analysis using primers EVD2 and EVU2 (table 3) where primer EVD2 was biotinylated. Biotinylated PCR products were captured on streptavidin coated magnetic beads (Dynal, Wirral) and denatured with $0.1 \mathrm{~mol} / 1$ sodium hydroxide to generate single stranded DNA. This was used as template in a sequencing reaction (Autoread; Pharmacia Biotech, St Albans) using fluorescein labelled EVU2 as sequencing primer.

Figure 2 Enterovirus $R N A$ detected by in situ hybridisation in myocardium from patient 2 showing a focus of virus infected myocytes.
Sequencing reactions were analysed using an ALF automated DNA sequencer (Pharmacia). Sequences were compared with published enterovirus sequences using DNASIS.

\section{Results}

Table 5 summarises the results of nested PCR amplification of RNA from heart samples from patients and controls. Enterovirus RNA was detected by PCR in five of six patients using both sets of primers in the $5^{\prime} \mathrm{NTR}$, and in two of four patients using VP2 primers. Two of three $\mathrm{H}$ and $\mathrm{E}$ samples were positive by PCR as were all four paraffin embedded blocks. No enteroviral RNA was found by PCR in the comparison group. Figure 1 shows the results of PCR studies on tissue from patient No 2 . Sequencing of PCR products from patients indicated that viruses detected most closely resembled CVB3 in four cases and CVB5 in one. Enterovirus RNA was also detected by in situ hybridisation in three of three patients with acute myocarditis (patient Nos 1,2 , and 4). Figure 2 shows the results of in situ hybridisation of myocardium from patient No 2. Enterovirus specific IgM was detected in four of five patients, one of whom had no detectable enteroviral RNA by PCR (No 6). Serum samples were not available from the control group for comparison.

\section{Discussion}

We have shown using nested RT and PCR, albeit on a small number of patients, that it is possible to detect enteroviral RNA in archival material collected up to 17 years before testing. This is encouraging as it is generally presumed that RNA is not very stable and cannot be detected in archival specimens. Our findings as well as those of others, ${ }^{19}{ }^{20}$ however, indicate that viral RNA is relatively stable and may be protected by the fixation process. The time interval between death and preservation of postmortem tissue may affect RNA preservation, as may the time spent in formalin before embedding. ${ }^{21}$ As the patients were referred from different centres over a long period of time, however, it was not possible to ascertain either of these intervals.

Comparatively few virological studies have been carried out on cases of acute myocarditis employing PCR. Such studies as have been reported are based on small patient numbers. $^{22-25}$ More emphasis has been placed on investigating chronic infections, particularly dilated cardiomyopathy. This may reflect the fact that severe acute myocarditis is a relatively uncommon disease, and endomyocardial biopsy specimens and cardiac explants obtained during transplantation are only rarely available. This study used three PCR assays to amplify three distinct regions of the viral genome. In all cases where enteroviral RNA was detected, positive results were obtained in at least two of the three assays (table 5). This provides further evidence that false positivity resulting from PCR product contamination did not occur and will in due course provide 
additional sequence data from the VP2 region to confirm the serotypic identity of viruses detected. The failure to detect viral RNA using primers to amplify the VP2 coding region in some patients may be due to the lower sensitivity of this assay or the greater sequence variability in this region of the genome, resulting in changes in primer recognition sequences.

The only heart sample from patients with acute myocarditis in which enteroviral RNA was not detectable by PCR (No 6) was found histologically to have giant cell myocarditis with an eosinophilic infiltrate. All the other patients had a predominantly lymphocytic infiltrate of myocardium. As yet there is no evidence implicating enteroviruses in the pathogenesis of giant cell myocarditis.

In preliminary studies we also detected enterovirus RNA by in situ hybridisation using a digoxygenin labelled CVB3 cDNA probe in three of three patients with acute myocarditis. We are currently evaluating the sensitivity and specificity of this method. In a recent study by Hilton $e t a l^{24}$ a complete correlation between in situ hybridisation and PCR was reported. As virus was detected in only two of 10 samples from patients with acute myocarditis, however, further study in larger numbers is required to provide definitive information on the relative sensitivities of PCR and in situ hybridisation. It may be possible to enhance the sensitivity of in situ detection by using in situ PCR. This would have the advantage of enhanced sensitivity while allowing localisation of enteroviral RNA in relation to the tissue architecture. This may provide information on the pathogenesis of myocardial injury

Enterovirus specific IgM responses were present in three of four patients in whom enterovirus RNA was detected in myocardium. The failure to detect an IgM response in one patient may be related to the time at which the serum was collected in relation to the disease process, or to antigenic differences between the virus that infected the patient and those used to prepare antigens for enterovirus specific IgM enzyme linked immunosorbent assay. Enterovirus specific IgM was also detected in the patient in whom enterovirus RNA was not detected in the myocardium. Although failure to detect viral RNA in myocardium could have been due to the focal distribution of virus infected cells (fig 3), this patient had giant cell myocarditis which is not known to be related to enterovirus infection. It is therefore more likely that the IgM response reflects a recent but unrelated infection.

Sequence analysis of the 5'NTR indicates that most viruses detected in myocardium showed greatest similarity to CVB3. The percentage homology between sequences of the PCR products and published sequences is high $(97-100 \%)$ (table 5). This reflects the high conservation of sequence among different enterovirus serotypes in this region of the genome. The predominance of CVB3 is in agreement with another recent study on patients with myocarditis and dilated car- diomyopathy. ${ }^{25}$ Having demonstrated that it is possible to detect enteroviral RNA from archival material, it may now be possible to conduct more extensive retrospective studies to address this issue. If these findings hold true for larger case numbers then this may have profound implications on the potential development of a vaccine specific for CVB3.

This work was funded by grants $90 / 92$ and PG92122 from the British Heart Foundation, and an equipment grant from the Royal Society. The authors thank Mr David Turvey, Department of Histopathology, and the cardiologists of St Thomas' Hospital; Dr Audrey Flower, PHLS Leicester Royal Infirmary; Dr John Coleman and Professor Henry, Westminster and Charing Cross Hospitals; Dr Primrose Watkins, St Mary's Hospital, Paddington, for providing clinical Watkins, St Mary's Hospital, Paddington, for providing clinical
material; Professor Reinhard Kandolf, University of Tuebingen, for the gift of plasmids pCB3 and p2723 and for suggesting the sequences of primers EVU3 and EVD4; Dr FA Lewis, University of Leeds, for advice on RNA extraction from $\mathrm{H}$ and $\mathrm{E}$ stained tissue sections, and Dr Nawal Darias, Department of Histopathology, St Thomas's Hospital, for her histological expertise.

1 Grist NR, Reid D. Epidemiology of viral infections of the heart. In: Banatvala JE, ed. Viral infections of the heart. London: Edward Arnold, 1993:23-31.

2 El-Hagrassy MMO, Coltart DJ, Banatvala JE. Coxsackie B virus-specific IgM responses in patients with cardiac and other diseases. Lancet 1980;ii:1160-2.

3 Frisk G, Torfason EG, Diderholm H. Reverse radioimmunoassays of IgM and IgG antibodies to coxsackie B viruses in patients with acute myopericarditis. $\mathcal{F}$ Med Virol 1984;14:191-200.

4 McCartney RA, Banatvala JE, Bell EJ. Routine use of $\mu$-antibody capture ELISA for the serological diagnosis of coxsackie B virus infections. F Med Virol 1986;19: 205-12.

5 Miller NA, Carmichael HA, Calder BD, et al. Antibody to coxsackie $B$ virus in diagnosing postviral fatigue syndrome. BMF 1991;302:140-3.

6 Easton AJ, Eglin RP. The detection of coxsackie virus RNA in cardiac tissue by in situ hybridisation. $f$ Gen Virol 1988;69:85-91.

7 Bowles NE, Richardson PJ, Olsen EGJ, Achard LC. Detection of coxsackie $B$ virus specific RNA sequences in myocardial biopsy samples from patients with myocarditis and dilated cardiomyopathy. Lancet 1986;i:1120-3.

8 Kandolf R, Canu A, Klingel K, et al. Molecular studies on enteroviral heart disease. In: Brinton MA, Heinz FX, eds. New aspects of positive-strand RNA viruses. Washington DC: American Society of Microbiology, Washington

9 Aretz HT, Billingham ME, Edwards WD, et al. Myocarditis: a histopathologic definition and classification. Am $\mathcal{F}$ Cardiovasc Pathol 1986;1:3-14.

10 Muir P, Banatvala JE. Reactivity of enterovirus-specific IgM with infective and defective coxsackie $B$ virions in patients with monotypic and multitypic IgM responses. $\mathcal{F}$ Virol Methods 1990;29:209-24.

11 Muir P, Nicholson F, Jhetam M, Neogi S, Banatvala JE. Rapid diagnosis of enterovirus infection by magnetic bead extraction and polymerase chain reaction detection of enterovirus RNA in clinical specimens. 7 Clin Microbiol of enterovirus

12 Nicholson F, Meetoo G, Aiyar S, Banatvala JE, Muir P. Detection of enterovirus RNA in clinical samples by nested polymerase chain reaction for rapid diagnosis of enterovirus infection. $\mathcal{F}$ Virol Methods 1994;48:155-66.

13 Iizuka N, Kuge S, Nomoto A. Complete nucleotide sequence of the genome of coxsackievirus B1. Virology 1987;156:64-73.

14 Klump WM, Bergmann I, Muller BC, Ameis D, Kandolf $R$. Complete nucleotide sequence of infectious coxsackievirus B3 cDNA: two initial $5^{\prime}$ uridine residues are regained during plus strand synthesis. $₹$ Virol $1990 ; 64(4)$ : regained $1573-83$.

15 Jenkins O, Booth JD, Minor PD, Almond JW. The complete nucleotide sequence of coxsackievirus B4 and its comparison to other members of picornaviridae. $\mathcal{F} \mathrm{Gen}$ Virol 1987;68:1835-48.

16 Zhang G, Wilsden G, Knowles NJ, McCauley JW. Complete nucleotide sequence of a coxsackie B5 virus and its relationship to swine vesicular disease virus. $\mathcal{F} \mathrm{Gen}$ Virol 1993;74:845-53.

17 Kandolf R, Hofschneider PH. Molecular cloning of the genome of a cardiotropic coxsackie B3 virus: full-length reverse-transcribed recombinant cDNA generates infectious virus in mammalian cells. Proc Natl Acad Sci USA 1985;82:4818-22.

18 Kandolf R, Ameis D, Kirschner P, et al. In situ detection of enteroviral genomes in myocardial cells by nucleic acid hybridization: an approach to the diagnosis of viral heart disease. Proc Natl Acad Sci USA 1987;84:6272-6. 
19 Woodall CJ, Watt NJ, Clements GB. Simple technique for detecting RNA viruses in single sections of wax embedded tissue. $\mathcal{f}$ Clin Pathol 1993;46:276-7.

20 Jackson DPP, Quirke F, Lewis AW, et al. Detection of measles virus RNA in paraffin-embedded tissue. Lancet 1989;i:1391.

21 Bresters D, Schipper MEI, Reesink HW, Boeser-Nunnink BDM, Cuypers HTM. The duration of fixation influences the yield of HCV CDNA-PCR products from formalin-fixed, paraffin-embedded liver tissue. $f$ Virol Methods 1994;48:267-72.

22 Jin O, Sole MJ, Butany JW, et al. Detection of enterovirus RNA in myocardial biopsies from patients with myocarditis and cardiomyopathy using gene amplification by polymerase chain reaction. Circulation 1990;82:8-16.

23 Severini GM, Mestroni L, Falaschi A, Camerini F, Giacca $M$. Nested polymerase chain reaction for high-sensitivity detection of enteroviral RNA in biological samples. $\mathcal{F}$ Clin Microbiol 1993;31(5): 1345-9.

24 Hilton DA, Variend S, Pringle JH. Demonstration of coxsackie virus RNA in formalin-fixed tissue sections from sackie virus RNA in formalin-fixed tissue sections from childhood myocarditis cases by in situ hybridization and 25 Khan M, Why H, Richardson P, Archard LC. Nucleotide sequencing of PCR products show the presence of Coxsackie-B3 virus in endomyocardial biopsies from patients with myocarditis or dilated cardiomyopathy. Biochem Soc Trans 1994;22:176S.

\section{IMAGES IN CARDIOLOGY}

\section{Hypertrophic cardiomyopathy}

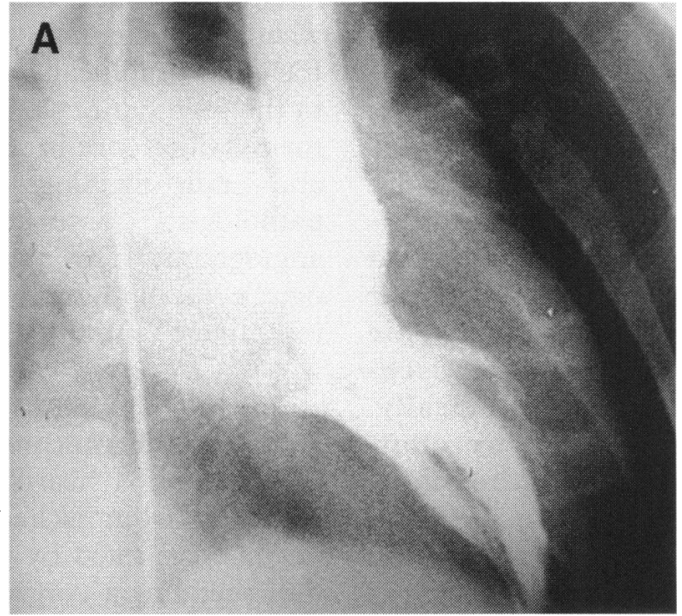

Figure $A$

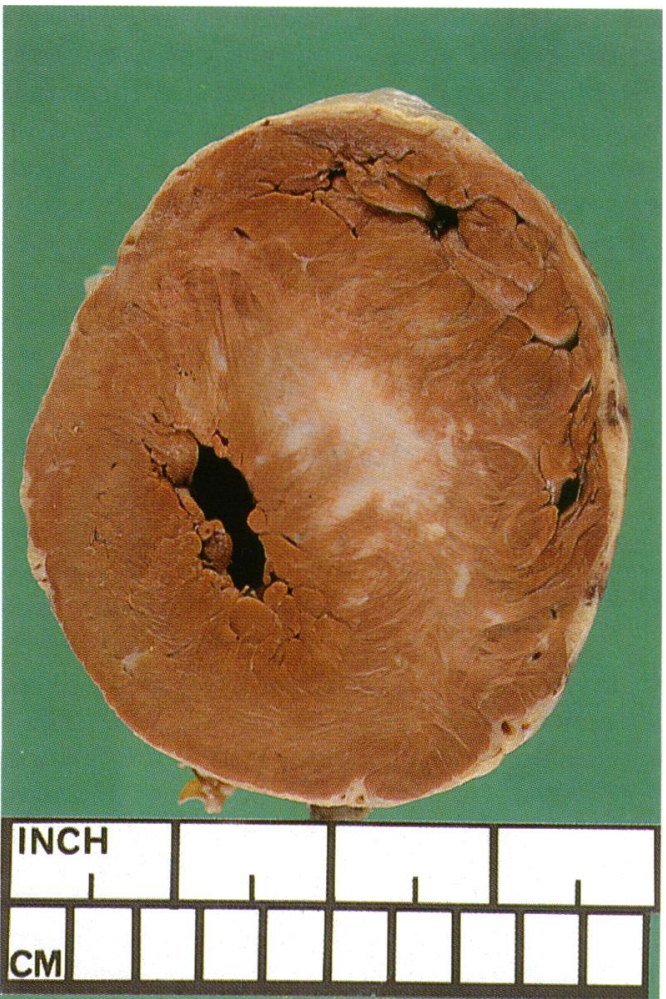

Figure $B$
A 60 year old woman presented with severe dyspnoea. A labile left ventricular outflow tract gradient varying between 20 and $80 \mathrm{~mm}$ $\mathrm{Hg}$ was demonstrated at cardiac catheterisation. The left ventricular angiogram (A) shows the typical appearances of hypertrophic cardio-myopathy with a very small end systolic cavity, hypertrophied papillary muscles, and associated severe mitral regurgitation.

(B) Postmortem transverse section through the heart at the level of the ventricles in a case of sudden death in a male patient, who was in his mid 20's, and found dead in the street in the early hours of the morning. There is intense left ventricular hypertrophy particularly affecting the interventricular septum (approximately $4.5 \mathrm{~cm}$ ) with associated fibrosis and virtual obliteration of the left and right ventricular cavities.

M K DAVIES 